\title{
PEMBERDAYAAN LIFE SKILLS BATIK SEKOLAH DASAR NEGERI (SDN) DI PANDAK KABUPATEN BANTUL DAERAH ISTIMEWA YOGYAKARTA
}

\author{
Suharjito \\ itosuharjito@gmail.com
}

\begin{abstract}
Abstrak
Penelitian ini bertujuan untuk mendeskripsikan model penyelenggaraan pemberdayaan seni batik di SDN di Kecamatan Pandak Kabupaten Bantul. Penelitian ini merupakan penelitian deskriptif dengan pendekatan kualitatif. Penelitian ini dilaksanakan di SDN Jigudan, SDN Gunturan, SDN Ciren yang terletak di sekitar desa Wijirejo Kecamatan Pandak Kabupaten Bantul. Subyek penelitian yakni pengelola sekolah, pendamping dan fasilitator dalam pemberdayaan life skills batik tersebut. Pengumpulan data dilakukan secara bertahap sesuai dengan apa yang menjadi kebutuhan peneliti. Teknik yang digunakan adalah observasi, wawancara dan dokumentasi. Tahapan analisis data dalam penelitian ini yaitu reduksi data, penyajian data dan penarikan kesimpulan. Reduksi data dimaksudkan dengan merangkum data, memilih hal-hal pokok, disusun secara sistematik. Penyajian data bertujuan untuk memudahkan peneliti memahami hasil penelitian yang telah didapatkan. Triangulasi sumber dilakukan untuk menjelaskan validitas data dengan berbagai narasumber dalam mencari informasi yang dibutuhkan. Pelaksanaan program pemberdayaan life skills batik SDN di Kecamatan Pandak dilaksanakan dengan melalui beberapa tahapan yaitu : (1) Menyusun renstra pendidikan dan pelatihan life skills batik melalui pemberdayaan bagi sekolah yang menjadi obyek dan subyek pelatihan. (2) Menyusun : a) kurikulum batik untuk siswa Sekolah Dasar, b) standar kompetensi membatik, c) indikator ketercapaian kompetensi membatik dan mengajar batik untuk para guru, d) menyusun indikator ketercapaian kompetensi membatik bagi siswa Sekolah Dasar. (3) Menyediakan instruktur yang berpengalaman untuk mendukung kegiatan pemberdayaan. (4) Menyusun jadwal pelatihan, jadwal tugas widyaiswara/instruktur. (5) Melaksanakan pemberdayaan dan monitoring pada setiap pelatihan batik. (6) Menyusun format monitoring kegiatan pemberdayaan batik. (7) Melakukan evaluasi dan melaporkan hasil pemberdayaan batik yang telah dilaksanakan setiap 3 bulan kepada pihak Astra International, Tbk. (8) Menggunakan strategi pelatihan in house trainning.
\end{abstract}

Kata kunci : pemberdayaan, life skills, batik

\section{Pendahuluan}

Batik Indonesia resmi dimasukkan dalam 76 warisan budaya tak benda oleh UNESCO, pada tanggal 30 September 2009, melalui keputusan komite 24 negara yang bersidang di Abu Dhabi, Uni Emirat Arab. (Sri Soedewi Samsi, 2011: xiv). Batik Indonesia dinilai kaya akan simbolsimbol yang berhubungan dengan status sosial, masyarakat lokal, alam, sejarah, dan warisan budaya yang memberikan identitas dan kelestarian bagi bangsa Indonesia sebagai komponen utama kehidupan mereka sejak lahir hingga meninggal, dan terus berevolusi tanpa menghilangkan makna tradisi. 
Upaya peningkatan kualitas sumber daya manusia melalui proses secara utuh menyeluruh (komprehensif), tidak hanya memperkuat basis akademik, tetapi juga ajaran agama dan pembinaan profesi atau keahlian (skill). Untuk itulah, maka sejak tahun 2002 Depdiknas telah mencanangkan sebuah program inovasi bidang pendidikan yang disebut dengan Program Life Skills (Pendidikan Kecakapan Hidup). Demikian juga dalam Undang-Undang Republik Indonesia Nomor 20 tahun 2003 tentang Sistem Pendidikan Nasional, khususnya pada penjelasan pasal 26 ayat 3 (Depdiknas, 2003:10), sehingga dikenal adanya dua program life skills, yaitu program life skills pendidikan sekolah dan program life skills PLS (Pendidikan Non Formal). Untuk itu pendidikan kecakapan hidup juga harus berjalan bersamaan dengan pendidikan vokasional.

Salah satu kawasan yang masih terus melanjutkan usaha membatik sebagai salah satu diantara mata pencaharian hidupnya yaitu dilakukan oleh sebagian masyarakat di Kecamatan Pandak, Kabupaten Bantul, Daerah Istimewa Yogyakarta. Kecamatan Pandak berada di sebelah barat daya dari Ibukota Kabupaten Bantul. Kecamatan Pandak mempunyai luas wilayah sebesar 4.069,8512 ha. Kecamatan Pandak berada di dataran rendah. Ibukota kecamatannya berada pada ketinggian 27 meter di atas permukaan laut. Jarak Ibukota Kecamatan ke Pusat Pemerintahan (Ibukota) Kabupaten Bantul adalah $5 \mathrm{~km}$. Kecamatan Pandak beriklim seperti layaknya daerah dataran rendah di daerah tropis dengan cuaca panas sebagai ciri khasnya. Suhu tertinggi yang tercatat di Kecamatan Pandak adalah $32^{\circ} \mathrm{C}$ dengan suhu terendah $20^{\circ} \mathrm{C}$. (https://www.bantulkab.go.id/kecamatan/Pandak, diakses. 22 Mei 2016)

Potensi kerajinan di Desa Wijirejo antara lain adalah usaha kerajinan batik di desa Pijenan yang memiliki kekhasan yaitu dengan batik khas Bantul. Letak SDN Jigudan, SDN Gunturan dan SDN Ciren yang secara geografis dekat dengan pusat kerajinan batik Wijirejo membuat anak-anak di sekitar desa Wijirejo akrab dengan dunia batik. Hal ini karena sebagian besar orang tua mereka mempunyai profesi sebagai pembatik dan perajin batik.

Sejak tahun 2012 PT. Astra International, Tbk. melalui Yayasan Pendidikan Astra Michael D. Ruslim (YPA MDR) bekerja sama dengan PPPPTK Seni dan Budaya Yogyakarta telah melakukan pendidikan dan pelatihan life skills batik terhadap guru dan siswa 3 (tiga) SDN Pandak Kabupaten Bantul Daerah Istimewa Yogyakarta. Masing-masing sekolah dilakukan pelatihan secara berkesinambungan selama tiga tahun berturut-turut.

Berdasarkan permasalahan tersebut, maka dipandang perlu adanya model pemberdayaan SDM Seni batik berperspektif life skills (Pendidikan Kecakapan Hidup/PKH) berbasis potensi lokal yang tidak semata-mata memfokuskan kepada penanaman kecakapan vokasional, tetapi yang secara komprehensif memadukan antara kecakapan non vokasional dengan kadar yang berimbang meliputi aspek-aspek pembelajaran, pemberdayaan, tindak lanjut sampai ke tahap kemandirian.

Penelitian ini bertujuan untuk mendeskripsikan model penyelenggaraan pemberdayaan kecakapan hidup seni batik yang telah dilakukan oleh PT. Astra International, Tbk. melalui Yayasan Pendidikan Astra - Michael D. Ruslim bekerja sama dengan PPPPTK Seni dan Budaya Yogyakarta. 


\section{Metode Penelitian}

Penelitian ini dilakukan dengan menggunakan pendekatan kualitatif yang berusaha menggambarkan dan menginterpretasi objek sesuai dengan apa adanya. Penelitian ini dilaksanakan di 3 (tiga) Sekolah Dasar Negeri (SDN) Kecamatan Pandak Kabupaten Bantul Yogyakarta yaitu SDN Gunturan, SDN Ciren dan SDN Jigudan. Penelitian ini dilakukan pada bulan April-Juni 2016. Subyek penelitian yakni pengelola sekolah baik guru dan kepala sekolah dan penyusun kurikulum, dan fasilitator dan pelaksana program dari Yayasan Pendidikan Astra - Michael D. Ruslim (YPA MDR) dalam pemberdayaan life skills batik tersebut. Pengumpulan data penelitian ini dilakukan secara bertahap sesuai dengan apa yang menjadi kebutuhan peneliti. Teknik yang digunakan adalah observasi, wawancara dan dokumentasi. Triangulasi sumber dilakukan untuk menjelaskan validitas data dengan berbagai narasumber dalam mencari informasi yang dibutuhkan.

Tahapan analisis data dalam penelitian ini yaitu reduksi data, penyajian data dan penarikan kesimpulan. Reduksi data dimaksudkan dengan merangkum data, memilih hal-hal pokok, disusun secara sistematik. Penyajian data bertujuan untuk memudahkan peneliti memahami hasil penelitian yang telah didapatkan. Data tersebut dibandingkan dan dihubungkan dengan yang lainnya, sehingga mudah ditarik kesimpulan sebagai jawaban dari setiap permasalahan yang ada.

Trianggulasi sumber dilakukan dengan cara mengecek data yang telah diperoleh melalui beberapa sumber yaitu kepala sekolah dan guru SDN Jigudan, penyusun kurikulum dan ketua pelaksana program YPA MDR. Data dari ketiga sumber tersebut dideskripsikan dan dikategorikasikan sehingga menghasilkan suatu kesimpulan.

\section{Temuan dan Pembahasan}

Menurut konsepnya, kecakapan hidup dapat dibagi menjadi dua jenis utama, yaitu: 1)Kecakapan hidup generik (generic life skill/GLS), dan 2) Kecakapan hidup spesifik (specific life skill/SLS). Masing-masing jenis kecakapan itu dapat dibagi menjadi sub kecakapan. Kecakapan hidup generik terdiri atas kecakapan personal (personal skill), dan kecakapan sosial (social skill). Kecakapan personal mencakup kecakapan dalam memahami diri (self awareness skill) dan kecakapan berpikir (thinking skill).

Kecakapan mengenal diri pada dasarnya merupakan penghayatan diri sebagai makhluk Tuhan Yang Maha Esa, sebagai anggota masyarakat dan warga negara, serta menyadari dan mensyukuri kelebihan dan kekurangan yang dimiliki sekaligus sebagai modal dalam meningkatkan dirinya sebagai individu yang bermanfaat bagi lingkungannya. Kecakapan berpikir mencakup antara lain kecakapan mengenali dan menemukan informasi, mengolah, dan mengambil keputusan, serta memecahkan masalah secara kreatif.

Sedangkan dalam kecakapan sosial mencakup kecakapan berkomunikasi (communication skill) dan kecakapan bekerja sama (collaboration skill). Kecakapan hidup spesifik adalah kecakapan untuk menghadapi pekerjaan atau keadaan tertentu. Kecakapan ini terdiri dari kecakapan akademik (academic skill) atau kecakapan intelektual, dan kecakapan vokasional (vocational skill). Kecakapan akademik terkait dengan bidang pekerjaan yang lebih 
memerlukan pemikiran atau kerja intelektual. Kecakapan vokasional terkait dengan bidang pekerjaan yang lebih memerlukan keterampilan motorik. Kecakapan vokasional terbagi atas kecakapan vokasional dasar (basic vocational skill) dan kecakapan vokasional khusus (occupational skill).

\section{Tujuan}

Penyelenggaraan pemberdayaan life skills seni batik bertujuan agar subyek memiliki kemampuan dalam:

1. Mengenal sejarah perkembangan dan memahami konsep pembuatan seni batik;

2. Menampilkan sikap apresiasi terhadap seni batik;

3. Menampilkan kreativitas dan produktivitas melalui seni batik;

4. Guru mampu untuk menyampaikan tujuan pendidikan dan pelatihan life skills batik kepada peserta didik, sehingga pada akhirnya peserta didik tersebut mampu membuat/menciptakan batik sesuai dengan tingkat usianya yang digali dan dikembangkan dari ciri khas batik di Pandak Bantul.

5. Siswa memiliki kompetensi dasar meliputi: menggambar, ikat celup, tetes lilin, membatik dan mewarna dengan bahan sintetis dan alami sesuai tingkatan atau kelasnya.

\section{Strategi Pembinaan}

\section{Pembinaaan selama 3 Tahun untuk Jenjang Sekolah Dasar}

\section{Tahun Pertama: Pembimbingan Langsung}

Kompetensi Dasar, guru menguasai kompetensi dasar yang harus diberikan kepada siswa, dengan penekanan pada penguasaan keterampilan (skill) dan teknik untuk setiap kompetensi.

\section{Tahun Kedua: Semi Modul}

Kompetensi Pengembangan, guru menguasai kompetensi pengembangan dengan bimbingan, penekanannya adalah mengembangkan kompetensi dasar untuk mencapai suatu kreativitas, yang berlandaskan pada kompetensi dasar dengan bimbingan semi modular.

\section{Tahun Ketiga: Modul}

Kompetensi Inventif, guru menguasai kompetensi inventif secara mandiri dengan menemukan teknik-teknik baru, metode baru, dan bahan baru. Khususnya yang berkenaan dengan seni batik dengan bimbingan modular.

\section{Tempat}

Tiga SDN Negeri Kecamatan Pandak meliputi; SDN Jigudan, SDN Gunturan, dan SDN Ciren. Secara keseluruhan jumlah siswa yang mengikuti kegiatan pendidikan dan pelatihan life skills batik dengan menata sebagai mata pelajaran ekstrakurikuler yang diselenggarakan oleh PPPPTK Seni dan Budaya Yogyakarta bekerja sama dengan PT. Astra International, Tbk. melalui Yayasan Pendidikan Astra - Michael D. Ruslim sejumlah 671 siswa dan 30 guru. Dengan rincian sebagai berikut: 


\begin{tabular}{|l|l|l|l|}
\hline No. & Nama Sekolah & Jumlah Siswa & Jumlah Guru \\
\hline 1 & SDN Jigudan & 297 & 12 \\
\hline 2 & SDN Gunturan & 278 & 12 \\
\hline 3 & SDN Ciren & 96 & 6 \\
\hline Jumlah & 671 & 30 \\
\hline
\end{tabular}

Tabel 1. Jumlah Siswa Dan Guru Tahun Ajaran 2015/2016

Sumber: Profil SD Jigudan, SD Gunturan dan SDN Ciren

\section{Alur Kegiatan}

Kegiatan dilakukan dengan alur secara bergantian setiap hari Selasa, Rabu dan Kamis berulang lagi setelah 7 putaran 3 sekolah (setiap 2 minggu satu putaran), dengan urutan sebagai berikut:

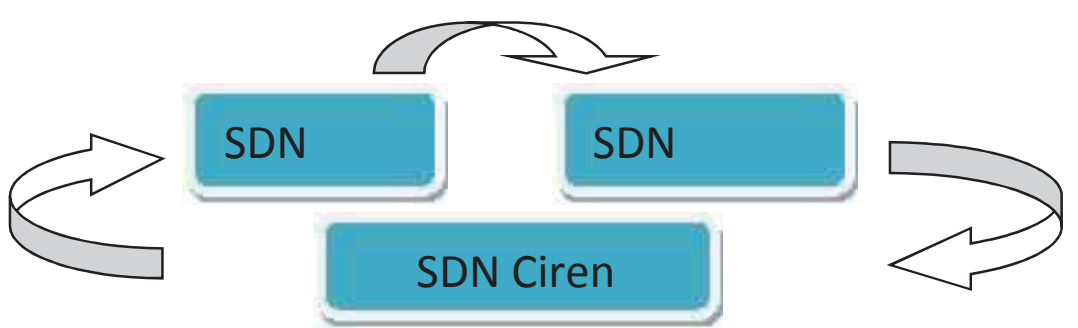

Gambar 1. Alur Kegiatan Pemberdayaan Seni Batik Sumber: Kurikulum Batik SD

\section{Materi Pemberdayaan Life Skills Batik}

1. Menggambar unsur-unsur rupa

Eksplorasi unsur-unsur rupa; titik, garis, bidang, dan warna.

2. Eksplorasi warna alami dan sintesis

Membuat komposisi unsur rupa dengan pewarnaan alami melalui teknik gores dan cetak di atas kertas dengan teknik gores dan cetak.

3. Menggambar ekspresif

Menggambar ekspresif bagian-bagian tumbuhan dan binatang di atas kertas, mengembangkan bentuk geometris menjadi suatu bentuk baru yang menarik di atas kertas, menggambar ekspresif kombinasi bentuk tumbuhan, binatang, dan bentuk geometris di atas kertas, menggambar ekspresif kombinasi bentuk tumbuhan, binatang, dan bentuk geometris dengan menggunakan warna alami dan sintetis di atas kertas; menggambar kombinasi bentuk-bentuk geometris secara menarik di atas kertas; dan menggambar komposisi bentuk-bentuk organis secara menarik di atas kertas.

4. Menggambar motif

Mengembangkan bagian-bagian tumbuhan menjadi sebuah motif sederhana di atas kertas dengan pewarnaan alami teknik gosok; mengembangkan bagian-bagian binatang menjadi sebuah motif sederhana di atas kertas dengan pewarnaan alami teknik tumbuk; mengembangkan bentuk tumbuhan menjadi sebuah motif sederhana di atas kertas dengan pewarnaan sintetis; mengembangkan bentuk binatang sebuah sebuah motif 
sederhana di atas kertas dengan pewarnaan sintetis; mengembangkan bentuk geometris menjadi motif bentuk motif di atas kertas dengan pewarnaan sintetis; meniru beberapa motif batik tradisional di atas kertas ukuran A4; mengembangkan secara sederhana beberapa motif batik tradisional di atas kertas; meniru beberapa motif modern di atas kertas; dan mengembangkan secara sederhana beberapa motif batik modern di atas kertas.

5. Ikat celup

Mengikat kain sutera secara sederhana sebagai dasar teknik ikat celup; mencelup kain yang telah diikat dengan warna alami untuk selendang.

6. Batik tetes lilin

Membuat karya batik secara ekspresif dengan teknik tetesan lilin dengan pewarnaan sintetis pada bahan kain katun.

7. Batik Tulis

Membuat karya batik tulis dengan pewarnaan sintetis pada bahan sandang yang meliputi: menggambar motif, memindahkan gambar motif batik tradisional dan modern dari atas kertas ke atas kain; mencanting, dan pewarnaan dengan warna sintetis.

Temuan dari hasil pemberdayaan life skills batik adalah sebagai berikut:

a. Pemilihan ketiga sekolah dasar yang menjadi sasaran pemberdayaan adalah berdasarkan dari study potensi yang dilakukan oleh tim survey dari YPA MDR dengan kesepakatan dan kesanggupan dari seluruh anggota sekolah baik guru, kepala sekolah dan pengurus sekolah.

b. Pengelolaan dan pemberdayaan SDM seni khususnya batik dapat dilakukan sejak dini untuk menanamkan rasa cinta dan memiliki warisan nenek moyangnya sehingga dapat dilestarikan keberadaannyaa oleh generasi penerusnya.

c. Siswa tumbuh menjadi siswa yang kreatif, toleran dan mencintai budaya bangsanya sendiri, terutama dalam bidang batik tulis yang ditekankan pada pewarna alami/nabati.

d. Seni batik tulis menjadi warisan dunia yang dapat dipertahankan dan dikembangkan keberadaannya.

e. Proses pembelajaran seni batik di Kecamatan Pandak dapat dikembangkan menjadi suatu model pemberdayaan SDM di bidang seni yang dapat diterapkan di sekolah lain.

f. Tumbuh berkembangnya dengan cepat pembelajaran seni di Indonesia dengan adanya kerja sama yang terprogram, sistematis dan berkelanjutan antara pihak pemerintah dan industri.

\section{Metode Pembelajaran}

Pembelajaran yang dilaksanakan dalam pemberdayaan life skills batik guru dan siswa SDN Kecamatan Pandak, Kabupaten Bantul adalah metode ceramah, diskusi, simulasi, praktek, demonstrasi dan penugasan pembuatan karya/gambar/tugas dengan permainan sesuai dengan kelasnya dilanjutkan dengan presentasi atau menceritakan proses pembuatan karya atau gambar secara bergantian. 
Pengelolaan sumber daya manusia di bidang seni terutama seni batik yang dilaksanakan atas inisiasi PT. Astra International, Tbk. melalui Yayasan Pendidikan Astra - Michael D. Ruslim merupakan salah satu upaya yang belum pernah dilaksanakan di sekolah yang lain. Pemberdayaan life skills batik ini merupakan pilot project yang nantinya diharapkan dapat dilaksanakan oleh sekolah lain yang memiliki potensi yang sama dengan daerah di Kecamatan Pandak Bantul Yogyakarta. Pemberdayaan life skills batik ini merupakan sebuah anak tangga yang tidak terputus dari tingkat sekolah dasar dari kelas I sampai kelas VI dimana anak mulai diperkenalkan sejak dini tentang ketrampilan membatik. Dengan proses penanaman sebagai berikut : kelas I; mengenal unsur-unsur dalam seni rupa, kelas II; menggambar motif batik, kelas III; mengenal warna alami yang dapat digunakan untuk mewarnai dan mempraktekkan batik ikat celup sederhana, kelas IV; membuat batik menggunakan tetesan lilin, kelas V; menggambar motif batik tradisional dan membuat batik tradisional, kelas VI; menggambar motif modern dan membuat batik modern. Kegiatan pemberdayaan life skills batik ini dilaksanakan selama satu tahun pelajaran penuh, dimana karya anak diharuskan selesai sebelum kenaikan kelas.

Selain anak, guru juga diperkenalkan tentang budaya membatik, guru memiliki peran yang penting dalam proses pemberdayaan, dimana guru memegang peran penting dalam proses pembelajaran kepada anak. Oleh karena itu, sasaran pemberdayaan life skills seni batik ini tidak hanya anak tetapi juga guru terutama guru wali kelas yang merupakan pendamping utama di setiap tingkatan kelas. Selain pada tingkat sekolah dasar, konsep pemberdayaan SDM di bidang seni batik ini juga dilaksanakan pada tingkat Sekolah Menengah Pertama (SMP) di Kabupaten Pandak yaitu di SMP Negeri 4 Pandak Bantul.

\section{Kesimpulan}

Pelaksanaan Program Pemberdayaan Life Skills Seni Batik SDN di Kabupaten Pandak dilaksanakan dengan melalui beberapa tahapan yaitu:

1. Menyusun renstra pendidikan dan pelatihan life skills batik melalui pemberdayaan bagi sekolah yang menjadi obyek dan subyek pelatihan.

2. Menyusun: (a)kurikulum batik untuk sekolah dasar dari kelas satu sampai dengan kelas enam, (b)standar kompetensi membatik lulusan sekolah dasar, (c)indikator ketercapaian kompetensi membatik dan mengajar batik untuk para guru dan, (d)menyusun indikator ketercapaian kompetensi membatik bagi siswa sekolah dasar kelas satu sampai dengan dengan kelas enam.

3. Menyediakan instruktur yang berpengalaman dalam jumlah yang cukup untuk mendukung kegiatan pelatihan tersebut.

4. Menyusun jadwal pelatihan, jadwal tugas widyaiswara/instruktur pelatihan/pembinaan.

5. Melaksanakan pemberdayaan dan monitoring pada setiap pelatihan batik.

6. Menyusun format monitoring kegiatan pelatihan/pembinaan batik;

7. Melakukan evaluasi dan melaporkan hasil pelatihan/pembinaan batik yang telah dilaksanakan bagi guru dan siswa, setiap 3 bulan kepada pihak Astra International, Tbk.

8. Strategi pelatihannya dengan In House Trainning (IHT). Pelatihan dalam bentuk IHT adalah pelatihan yang dilaksanakan secara internal di KKG/MGMP, sekolah atau 
tempat lain yang ditetapkan untuk menyelenggarakan pelatihan. Strategi pembinaan melalui IHT dilakukan berdasarkan pertimbangan bahwa sebagian kemampuan dalam meningkatkan kompetensi dan karir guru tidak harus dilakukan secara eksternal, tetapi dapat dilakukan oleh guru yang memiliki kompetensi kepada guru lain yang belum memiliki kompetensi. Dengan strategi ini diharapkan dapat lebih menghemat waktu dan biaya.

\section{Saran}

1. Kerja sama antara PPPPTK Seni dan Budaya Yogyakarta dengan PT. Astra International, Tbk. melalui Yayasan Pendidikan Astra - Michael D. Ruslim, memberikan konstribusi yang positif bagi regenerasi peranjin/pengusaha batik. Untuk itu perlu didukung dari semua stakeholders terkait.

2. Pasca pemberdayaan merupakan proses peralihan tugas dan fungsi untuk kelangsungan pemberdayaan, untuk itu diperlukan suatu rencana yang matang yang melibatkan semua unsur agar inisiasi yang telah dilakukan dapat dikembang-tumbuhkan secara signifikan.

3. Dukungan nyata dari Pemerintah dan Pemerintah Daerah perlu dilakukan secara konkrit, termasuk dari Dinas Pendidikan Pemuda dan Olah Raga Kabupaten dan Provinsi, sehingga kedua daerah tersebut perekonomiannya tumbuh berbasis pada potensi lokal, dan menjadikan posisi dari masyarakat pra-sejahtera menuju ke masyarakat sejahtera tingkat pertama atau kedua.

\section{Kepustakaan}

Ambar Teguh S.(2004). Kemitraan dan Model-Model Pemberdayaan. Yogyakarta: Gava Media.

Moleong, Lexy. (2012). Metodologi Peneletian Kualitatif. Bandung: PT. Rosdakarya.

Safri Miradj, Sumarno. (2014). Pemberdayaan Masyarakat Miskin melalui Proses Pendidikan Non Formal, Upaya Meningkatkan Kesejahteraan Sosial di Kabupaten Halmahera Barat. http://journal.uny.ac.id/ diakses pada tanggal 23 Agustus 2016.

Salviana, Vina dan Widyasturi, Dyah Erni. (2008). Pemberdayaan Perempuan Usia Produktif Melalui Pengembangan Model Life Skills (Pendidikan Kecakapan Hidup) Berbasis Potensi Lokal. Laporan Penelitian Hibah Bersaing Th 1. Ditlitabmas Dirjen Dikti. Tidak dipublikasikan.

Soedewi Samsi, Sri. (2011). Teknik dan Ragam Hias Batik Yogya \& Solo. Yayasan Titian Masa Depan (Titian Foundation).

Sriyana, Pulung. (2012). Pelaksanaan Pendidikan Dan Pelatihan Life Skills Batik Pada 3 (Tiga) Sd dan Smp di Pandak Kabupaten Bantul, Daerah Istimewa Yogyakarta, Laporan Evaluasi Pelaksanaan Pemberdayaan Lifeskills Batik Th 3, PPPPTK Seni Budaya, Tidak Dipublikasikan.

Sugiyono, (2015). Metode Penelitian Manajemen. Bandung: Penerbit Alfabeta

(https://www.bantulkab.go.id/kecamatan/Pandak, diakses. 22 Mei 2016) 